west of $c .51^{\circ}$ longitude. East of this, the marine limit seems to be under $70-90 \mathrm{~m}$, but precise determination of the limit is complicated by interference with fluvial terraces and ice-margin deposits. Nonetheless, a moderately well developed 70-72 m strandline occurs along both the north and south shores of Umivit from $50^{\circ} 53^{\prime}$ to $51^{\circ} 03^{\prime} \mathrm{W}$. This strandline is shown to represent the marine limit by both a 73-75 $\mathrm{m}$ lower limit of perched boulders and a $60 \mathrm{~m}$ upper limit of sparsely fossiliferous, marine clay rich in organic material. The strandline is also clearly expressed as a wavecut terrace in morainic ice-margin deposits along the south-east shore of Umîvit and, therefore, indicates that the position of the ice-margin at this locality formerly corresponded to the $c .70 \mathrm{~m}$ sea level. A possibly significant ice-margin readvance is also suggested in this area by deformed and faulted marine deposits in which fragmented shells occur along fault planes. The boundary of change in marine limit at $51^{\circ} \mathrm{W}$ seems to coincide with the "fjord stages" of Weidick (1968).

For the lower marine deposits a transition in marine limit seems to occur around $50^{\circ} 30^{\prime}$ to $51^{\circ} \mathrm{W}$. West of this shell-rich layers, mostly in silts, occur up to $70-80 \mathrm{~m}$, whereas to the east the marine deposits are more sparse and occur only up to $40-50 \mathrm{~m}$. Their occurrence also seems to be restricted to certain valleys; although shell-bearing concretions in the southern branch of Nordre Strømfjord occur in marine silt that was pushed up to the frontal moraines of the Inland Ice in historical time, shells have not been found either in the laminated silt of the terraces in the inner part of Nordre Isortoq ("Isortoqelven") or in the valleys inside the inner branches of Søndre Strømfjord, where the eastern limit of fossiliferous deposits seems to be $50^{\circ} 30^{\prime} \mathrm{W}$.

\title{
Reference
}

Weidick, A. 1968: Observations on some Holocene glacier fluctuations in West Greenland. Bull. Gronlands geol. Unders. 73 (also Meddr Gronland 165, 6).

\section{THE NEW GGU BASE IN THE FISKENÆSSET AREA}

\section{G. Henderson}

During the summer the GGU base was moved from Mellembygden to north of Fiskenæsset. The new base, which has been given the name Midgård (old Norse the home of man), is situated at the mouth of a large river entering the sound Sarfat âriât, $16 \mathrm{~km}$ in a direct line north-north-east of the fishing village of Fiskenæsset. The journey by ship from Fiskenæsset to the base takes about two hours, the route lying either east or west of the large island of Qeqertarssuatsiaq. The main buildings are situated on the middle and largest of three terraces at the mouth of the river, and the camp area lies $20 \mathrm{~m}$ above sea level. 
The writer spent the summer in the new area and travelled throughout much of the region from Frederikshåbs Isblink up to Fiskenæsfjorden. The main object was to learn as much as possible about the geology and problems of access and supply to facilitate planning of future work. Much of the western part of the area has been mapped in reconnaissance form by B. F. Windley, and the writer had the benefit of having photographic copies of Windley's maps. Some of the coast sections were re-examined and a few areas were mapped in detail.

The western part of the area is covered by good topographic maps at a scale of $1: 20000$. The only maps available in the eastern part of the area are at a scale of $1: 250000$. After a summer in the field it became clear that it would be desirable to map the whole area on base maps at a scale of 1:20 000. GGU therefore approached a private firm to find out whether it would be possible to produce acceptable base maps using available vertical aerial photography and existing point control. The firm is at present working on a trial strip, and if this is a success the work will be extended to cover the whole of the area where 1:20000 maps are lacking at present.

On the basis of what is known of the regional geology and on the basis of the topography, the region between Frederikshåbs Isblink and the fjord system south of the base, but excluding for the time being the area south-east of the innermost part of Fiskenæsfjorden, has been divided into nine areas, each about $250 \mathrm{~km}^{2}$, for mapping. Each area will be for one geologist with an assistant and will be for two summers.

In addition to the nine mapping teams, one geologist will be in the area to make a special study of the sapphirine-bearing rocks. It is also probable that GGU will be supporting surveyors from the Geodetic Institute and an entomologist making a study of the small black flies (Simulium) with a view to finding a method for reducing their number locally.

Two helicopters will be stationed at the base during the summer and will be available for reconnaissance work and for checking of areas mapped, as well as for moving camps. GGU will also have ships in the area for work in coastal waters.

The 1970 field season will start in mid-June and continue until the end of August.

\section{BASIC ROCKS OF THE GARDAR IGNEOUS PROVINCE}

\section{B. G. J. Upton}

The mapping of south-west Greenland by the GGU to a scale of $1: 20000$ has revealed a profusion of unmetamorphosed dolerite dykes within the Precambrian basement. Although obviously younger than the latest regional metamorphic event, these basic rocks are either older than, or approximately contemporaneous with, such central igneous complexes as Ilímaussaq and Kûngnât, and it is now clear that basic mag- 